\title{
THE
}

\section{Rhizoleucinoside, a Rhamnolipid-Amino Alcohol Hybrid from the Rhizobial Symbiont Bradyrhizobium sp. BTAi1}

Jianwei Chen

Jiandong Sun

University of Rhode Island, iadong_sun@uri.edu

Robert W. Deering

University of Rhode Island, rdeering19@uri.edu

Navindra P. Seeram

University of Rhode Island, nseeram@uri.edu

Follow Whis and additional works at: https://digitalcommons.uri.edu/bps_facpubs

The University of Rhode Island Faculty have made this article openly available.

Please let us know how Open Access to this research benefits you.

This is a pre-publication author manuscript of the final, published article.

Terms of Use

This article is made available under the terms and conditions applicable towards Open Access

Policy Articles, as set forth in our Terms of Use.

\section{Citation/Publisher Attribution}

Chen, J., Sun, J., Deering, R. W., DaSilva, N., Seeram, N. P., Wang, H., \& Rowley, D. C. (2016).

Rhizoleucinoside, a Rhamnolipid-Amino Alcohol Hybrid from the Rhizobial Symbiont Bradyrhizobium sp.

BTAi1. Organic Letters, 18(6), 1490-1493. doi: 10.1021/acs.orglett.6b00461

Available at: http://dx.doi.org/10.1021/acs.orglett.6b00461

This Article is brought to you for free and open access by the Biomedical and Pharmaceutical Sciences at DigitalCommons@URI. It has been accepted for inclusion in Biomedical and Pharmaceutical Sciences Faculty Publications by an authorized administrator of DigitalCommons@URI. For more information, please contact digitalcommons-group@uri.edu. 


\section{Authors}

Jianwei Chen, Jiandong Sun, Robert W. Deering, Navindra P. Seeram, Hong Wang, and David C. Rowley 


\title{
Rhizoleucinoside, Rhamnolipid-Amino Alcohol Hybrid from the Rhi- zobial Symbiont Bradyrhizobium sp. BTAi1
}

\author{
Jianwei Chen, ${ }^{\dagger, \S}$ Jiadong Sun, ${ }^{\ddagger} \S$ Robert W. Deering, ${ }^{\dagger}$ Nicholas DaSilva, ${ }^{\ddagger}$ Navindra P. Seeram, ${ }^{\ddagger}$ Hong \\ Wang, ${ }^{* \dagger}$ and David C. Rowley*, \\ ${ }^{\dagger}$ College of Pharmaceutical Science, Zhejiang University of Technology, Hangzhou, Zhejiang, China, 310014, and \\ ${ }^{\ddagger}$ Department of Biomedical and Pharmaceutical Sciences, College of Pharmacy, University of Rhode Island, Kingston, RI, \\ United States, 02881
}

Supporting Information Placeholder

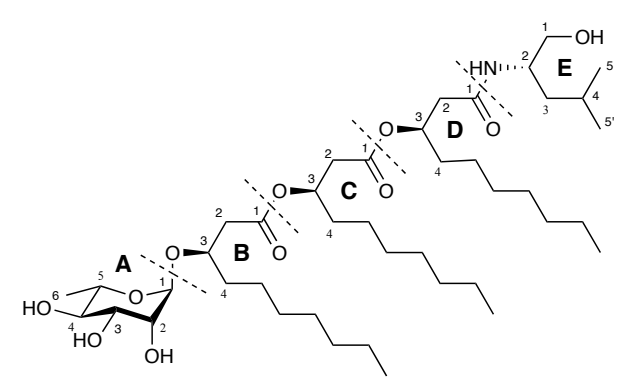

ABSTRACT: Rhizoleucinoside (1), a unique rhamnolipid-amino alcohol hybrid was isolated from the rhizobial symbiont bacteria Bradyrhizobium sp. BTAi1. 1 features a rare rhamnolipid core attached to an unprecedented leucinol moiety. Its structure and absolute configuration were determined by spectroscopic analysis, tandem mass spectrometry, chemical degradation and application of the Marfey's method. 1 possesses moderate cytotoxicity to BV-2 murine microglia and highly aggressive proliferating immortalized (HAPI) rat microglia cells.

Rhamnolipids are a group of biosurfactants produced by bacteria and their amphiphilic property originates from their glycolipidic structures. ${ }^{1}$ Rhamnolipids were first isolated from the opportunistic human pathogen Pseudomonas aeruginosa. ${ }^{2}$ More recent studies have expanded the bacteria taxa known to produce rhamnolipids to include new families such as $\mathrm{Aci}$ netobacter calcoaceticus from the family Moraxellaceae, ${ }^{3}$ different orders such as Pseudoxanthomonas sp. from the order Xanthomonadales, ${ }^{4}$ and even different classes such as Burkholderia spp. from the class Betaproteobacteria., ${ }^{5,6}$ Despite the production of rhamnolipids over disparate taxonomic groups, their biological function is still unclear. Studies suggest rhamnolipids might play multifunctional roles such as promoting the uptake of water insoluble substrates, ${ }^{7}$ immune modulators, ${ }^{8}$ antimicrobials, ${ }^{9}$ and insecticides. ${ }^{10}$ The common core structures are composed of one or two L-rhamnoses linked to one or two $\beta$-hydroxy fatty acids $\left(\mathrm{C}_{10}-\mathrm{C}_{16}\right)$ through a glycosidic bond. $\beta$-Hydroxy fatty acids are linked through ester bonds while di-saccharides are linked through $\alpha-1,2$ glycosidic linkages. ${ }^{1}$

In the study presented here, an unprecedented rhamnolipidamino alcohol hybrid rhizoleucinoside (1) (Figure 1), featuring a rare $\mathrm{Rha}-\mathrm{C}_{10}-\mathrm{C}_{10}-\mathrm{C}_{10}$ glycolipid core attached to a terminal leucinol moiety, was isolated from Bradyrhizobium sp. BTAi1 (ATCC BAA-1182). Bradyrhizobium species are symbiotic bacteria that fix nitrogen for their leguminous host plants. ${ }^{11}$
Although the whole genome of this strain has been sequenced, ${ }^{11}$ secondary metabolites have not been previously reported for this organism. To the best of our knowledge, this is the first example of an amino alcohol-containing rhamnolipid as well as the first rhamnolipid isolated from a bacterium belonging to the class Alphaproteobacteria.

1 was isolated as an amorphous, colorless solid, $[\alpha]^{23.2}-13.7$ (c $0.1, \mathrm{MeOH})$ from culture extracts of Bradyrhizobium sp. BTAil. The molecular formula of $\mathbf{1}$ was established as $\mathrm{C}_{42} \mathrm{H}_{79} \mathrm{NO}_{11}$ on the basis of the HRESIMS ion at $\mathrm{m} / z 774.5730$ $[\mathrm{M}+\mathrm{H}]^{+}$(calcd for $\mathrm{C}_{42} \mathrm{H}_{80} \mathrm{NO}_{11}, 774.5726$ ) and its sodium adduct ion $\mathrm{m} / \mathrm{z} 796.5556[\mathrm{M}+\mathrm{Na}]^{+}$. The IR spectrum showed a broad absorbance for $\mathrm{OH}$ and $\mathrm{NH}\left(\sim 3320 \mathrm{~cm}^{-1}\right)$ and sharp absorbances for $\mathrm{C}=\mathrm{O}\left(1736 \mathrm{~cm}^{-1}\right.$ for ester and $1646 \mathrm{~cm}^{-1}$ for amide) and C-O (1042 $\left.\mathrm{cm}^{-1}\right)$.

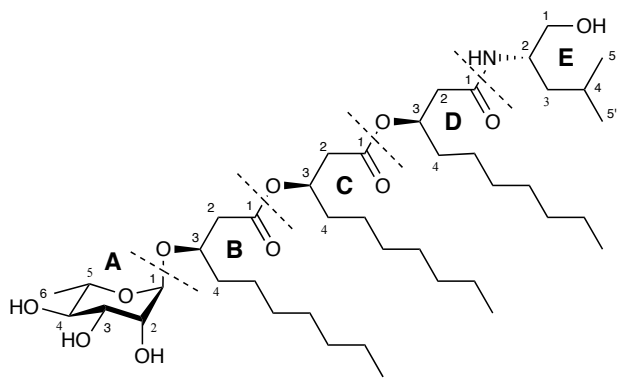

Figure 1. Structure of rhizoleucinoside (1). 
Table 1. ${ }^{1} \mathrm{H}(500 \mathrm{MHz})$ and ${ }^{13} \mathrm{C}(125 \mathrm{MHz})$ NMR data of 1 in DMSO- $d_{6}$

\begin{tabular}{|c|c|c|c|c|}
\hline no. & $\delta(\mathrm{ppm})$, type & $\delta_{\text {н }}(\mathrm{ppm})(\mathrm{mult}, J(\mathrm{~Hz}))$ & ${ }^{1} \mathrm{H}-{ }^{1} \mathrm{H} \operatorname{COSY}$ & ${ }^{1} \mathrm{H}-{ }^{13} \mathrm{C} \mathrm{HMBC}$ \\
\hline A1 & $100.2, \mathrm{CH}$ & $4.62, \mathrm{~d}(1.3)$ & A2 & $\mathrm{A} 2, \mathrm{~A} 5, \mathrm{~B} 3$ \\
\hline A2 & $71.2, \mathrm{CH}$ & $3.53, \mathrm{~m}$ & $\mathrm{~A} 1, \mathrm{~A} 2, \mathrm{~A} 2-\mathrm{OH}$ & $\mathrm{A} 3, \mathrm{~A} 4$ \\
\hline $\mathrm{A} 2-\mathrm{OH}$ & & $4.65, \mathrm{~d}(5.6)$ & $\mathrm{A} 2$ & $\mathrm{~A} 3$ \\
\hline A3 & 71.0, $\mathrm{CH}$ & $3.35, \mathrm{~m}$ & $\mathrm{~A} 2, \mathrm{~A} 4, \mathrm{~A} 3-\mathrm{OH}$ & \\
\hline $\mathrm{A} 3-\mathrm{OH}$ & & $4.48, \mathrm{~d}(6.1)$ & A3 & A2 \\
\hline A4 & $72.3, \mathrm{CH}$ & $3.15, \mathrm{~m}$ & $\mathrm{~A} 3, \mathrm{~A} 5, \mathrm{~A} 4-\mathrm{OH}$ & \\
\hline $\mathrm{A} 4-\mathrm{OH}$ & & $4.69, \mathrm{~d}(4.8)$ & A4 & A4 \\
\hline A5 & $69.2, \mathrm{CH}$ & $3.44, \mathrm{~m}$ & $\mathrm{~A} 4, \mathrm{~A} 6$ & $\mathrm{~A} 3, \mathrm{~A} 4$, \\
\hline A6 & $18.2, \mathrm{CH}_{3}$ & $1.08, \mathrm{~d}(6.2)$ & A5 & A5 \\
\hline B1 & $170.3, \mathrm{qC}$ & & & \\
\hline B2 & $39.0, \mathrm{CH}_{2}$ & $2.41, \mathrm{dd}(14.0,7.5), 2.46$ & B3 & B1, B3 \\
\hline B3 & $74.3, \mathrm{CH}$ & $3.85, \mathrm{~m}$ & $\mathrm{~B} 2, \mathrm{~B} 4$ & $\mathrm{~A} 1, \mathrm{~B} 1, \mathrm{~B} 4$ \\
\hline B4 & $33.8, \mathrm{CH}_{2}$ & $1.43, \mathrm{~m}$ & B3 & \\
\hline B5-B9 & $22.5-31.6, \mathrm{CH}_{2}$ & $1.19-1.27, \mathrm{~m}$ & & \\
\hline B10 & $14.5, \mathrm{CH}_{3}$ & $0.84, \mathrm{~m}$ & & \\
\hline $\mathrm{C} 1$ & $169.4, \mathrm{qC}$ & & & \\
\hline $\mathrm{C} 2$ & $40.6, \mathrm{CH}_{2}$ & $2.45, \mathrm{~m}, 2.53, \mathrm{~m}$ & $\mathrm{C} 3$ & $\mathrm{C} 1, \mathrm{C} 3$ \\
\hline $\mathrm{C} 3$ & $70.3, \mathrm{CH}$ & $5.04, \mathrm{~m}$ & $\mathrm{C} 2, \mathrm{C} 4$ & B1 \\
\hline $\mathrm{C} 4$ & $33.5, \mathrm{CH}_{2}$ & $1.52, \mathrm{~m}$ & $\mathrm{C} 3$ & \\
\hline C5-C9 & $22.5-31.6, \mathrm{CH}_{2}$ & $1.18-1,25, \mathrm{~m}$ & & \\
\hline $\mathrm{C} 10$ & $14.5, \mathrm{CH}_{3}$ & $0.84, \mathrm{~m}$ & & \\
\hline D1 & $168.7, \mathrm{qC}$ & & & \\
\hline D2 & $40.4, \mathrm{CH}_{2}$ & $2.29, \mathrm{dd}(14.0,5.5), 2.33 . \mathrm{dd}(14.0,7.9)$ & D3 & D1, D3 \\
\hline D3 & $71.8, \mathrm{CH}$ & $5.08, \mathrm{~m}$ & D2, D4 & $\mathrm{C} 1$ \\
\hline D4 & $33.5, \mathrm{CH}_{2}$ & $1.46, \mathrm{~m}$ & D3 & \\
\hline D5-D9 & $22.5-31.6, \mathrm{CH}_{2}$ & $1.17-1.24, \mathrm{~m}$ & & \\
\hline D10 & $14.5, \mathrm{CH}_{3}$ & $0.84, \mathrm{~m}$ & & \\
\hline E1 & $64.2, \mathrm{CH}_{2}$ & $3.16, \mathrm{~m}, 3.27, \mathrm{~m}$ & E1-OH & \\
\hline E1-OH & & $4.56, \mathrm{t}(5.5)$ & E1 & $\mathrm{E} 1, \mathrm{E} 2$ \\
\hline E2 & 49.0, $\mathrm{CH}$ & $3.76, \mathrm{~m}$ & E2-NH & \\
\hline E2-NH & & $7.54, \mathrm{~d}(8.7)$ & E2 & E2 \\
\hline E3 & $40.3, \mathrm{CH}_{2}$ & $1.23, \mathrm{~m}$ & & \\
\hline E4 & $24.7, \mathrm{CH}$ & $1.53, \mathrm{~m}$ & & \\
\hline E5 & $22.2, \mathrm{CH}_{3}$ & $0.79, \mathrm{~d}(6.5)$ & $\mathrm{E} 4$ & $\mathrm{E} 4$ \\
\hline E5, & $23.8, \mathrm{CH}_{3}$ & $0.84, \mathrm{~d}$ & E4 & E4 \\
\hline
\end{tabular}

The ${ }^{1} \mathrm{H}$ (Table 1) and HSQC NMR spectra of $\mathbf{1}$ in DMSO- $d_{6}$ showed a methine proton at $\delta_{\mathrm{H}} 4.62$ bound to a di-oxygenated carbon at $\delta_{\mathrm{c}} 100.2$, four methine protons between 3.15 and $3.53 \mathrm{ppm}$ correlating with oxygenated $\mathrm{sp}^{3}$ carbons between 69.1 and $78.8 \mathrm{ppm}$, three exchangeable protons between 4.48 and $4.69 \mathrm{ppm}$, and one methyl group $\left(\delta_{\mathrm{H}} 1.08 / \delta_{\mathrm{c}} 18.2\right)$. gCOSY and zTOCSY NMR spectra revealed a spin system (Figure 2) comprising anomeric proton $\mathrm{H}-\mathrm{A} 1\left(\delta_{\mathrm{H}} 4.62\right), \mathrm{H}-\mathrm{A} 2\left(\delta_{\mathrm{H}} 3.53\right)$, $\mathrm{H}-\mathrm{A} 3\left(\delta_{\mathrm{H}} 3.35\right), \mathrm{H}-\mathrm{A} 4\left(\delta_{\mathrm{H}} 3.15\right), \mathrm{H}-\mathrm{A} 5\left(\delta_{\mathrm{H}} 3.44\right)$ and H-A6 $\left(\delta_{\mathrm{H}}\right.$ 1.08 ), suggesting the presence of a 6-deoxyhexosyl subunit. 
This subunit was designated here as subunit A. Subunit A was determined to be rhamnopyranosyl by High Performance Anion Exchange Chromatography coupled with Pulsed Amperometric Detection (HPAEC-PAD) analysis of the hydrolyzed 1 in comparison with monosaccharide standards. The absolute stereochemistry of subunit A was determined after complete hydrolysis of $\mathbf{1}$. By measurement of optical rotation, rhamnose purified from $\mathbf{1}$ hydrolysates was determined to be L-rhamnose $[\alpha]^{20}+7.9\left(c 0.1, \mathrm{H}_{2} \mathrm{O}\right){ }^{12}$ The diequatorial coupling between anomeric proton H-A1 and H-A2 $\left(J_{1,2}=1.3\right.$ $\mathrm{Hz})^{13}$ indicated the glycosidic bond of L-rhamnopyranosyl moiety was in the $\alpha$ conformation.

The ${ }^{1} \mathrm{H}$, gCOSY and HSQC NMR spectra of $\mathbf{1}$ also showed one oxygenated methylene $\left(\delta_{\mathrm{H}} \mathrm{Ha} 3.16 / \mathrm{Hb} 3.27 / \delta_{\mathrm{c}} 64.2\right)$, one methine $\left(\delta_{\mathrm{H}} 3.76 / \delta_{\mathrm{c}} 49.0\right)$ bound to a secondary amine at $\delta_{\mathrm{H}}$ 7.54 , one aliphatic methylene $\left(\delta_{\mathrm{H}} 1.23 / \delta_{\mathrm{c}} 40.3\right)$, one aliphatic methine $\left(\delta_{\mathrm{H}} 1.53 / \delta_{\mathrm{c}} 24.7\right)$ and two aliphatic methyl groups $\left(\delta_{\mathrm{H}}\right.$ $0.79 / \delta_{\mathrm{c}} 22.2$ and $\left.\delta_{\mathrm{H}} 0.84 / \delta_{\mathrm{c}} 23.8\right)$. This subunit was designated as subunit E. The gCOSY and zTOCSY NMR spectra revealed a spin system along the hydroxyl methylene $\mathrm{H}-\mathrm{E} 1\left(\delta_{\mathrm{H}}\right.$ $\left.\mathrm{H}_{\mathrm{a}} 3.16 / \mathrm{H}_{\mathrm{b}} 3.27\right)$, amine bound methine H-E2 $\left(\delta_{\mathrm{H}} 3.76\right), \mathrm{H}-\mathrm{E} 3$ $\left(\delta_{\mathrm{H}} 1.23\right), \mathrm{H}-\mathrm{E} 4\left(\delta_{\mathrm{H}} 1.53\right)$ and the two methyls H-E5 $\left(\delta_{\mathrm{H}} 0.79\right)$ and H-E5' $\left(\delta_{\mathrm{H}} 0.84\right)$, suggesting the presence of a leucinol subunit. Correlation between the amine proton $\left(\delta_{\mathrm{H}} 7.54\right)$ and carbonyl carbon $\left(\delta_{\mathrm{c}} 168.7\right)$ in the HMBC spectrum indicated that the leucinol subunit connected to the rest of $\mathbf{1}$ through an amide bond. The chirality of leucinol purified from 1 hydrolysates was determined by reaction with Marfey's reagent and comparison with the retention time of its FDAA derivative with L-leucinol and D-leucinol standards FDAA derivatives. Marfey's method has been previously used to determine the stereochemistry of amino alcohols such as alaninol and valinol. ${ }^{14}$ To further validate this method for leucinol, L-leucinol and D-leucinol standards were derivatized with Marfey's reagent and analyzed by reversed phase HPLC. By comparison of the HPLC retention time, the amino alcohol subunit in $\mathbf{1}$ was determined to be L-leucinol.

In addition to the resonances belonging to rhamnopyranosyl and leucinol subunits, ${ }^{1} \mathrm{H}$ and ${ }^{13} \mathrm{C}$ NMR spectra showed three sets of resonances sharing highly similar structural features. The ${ }^{13} \mathrm{C}$ NMR spectrum showed three carbonyl carbons at $\delta_{\mathrm{c}}$ $168.7, \delta_{c} 169.4$ and $\delta_{c} 170.3$, three oxygenated methine carbons at $\delta_{\mathrm{c}} 70.3, \delta_{\mathrm{c}} 71.8$ and $\delta_{\mathrm{c}} 74.3$, three $\alpha$-methylene carbons at $\delta_{\mathrm{c}}$ $39.0, \delta_{\mathrm{c}} 40.4$ and $\delta_{\mathrm{c}} 40.6$, and three long aliphatic chains with highly overlapped resonances, consistent with three $\beta$ hydroxyl fatty acid subunits designated here as B, C and D. The gCOSY and zTOCSY spectra revealed partial features of the spin systems. For subunit $B$, a partial spin system was observed along $\alpha$-methylene protons $B-H 2\left(\delta_{H} H_{a} 2.41 / H_{b} 2.46\right)$, oxygenated methine $\mathrm{B}-\mathrm{H} 3\left(\delta_{\mathrm{H}} 3.85\right)$, aliphatic methylene $\mathrm{B}-\mathrm{H} 4$ $\left(\delta_{\mathrm{H}} 1.43\right)$ and a group of methylene resonances between $\delta_{\mathrm{H}}$ $1.12 \mathrm{ppm}$ and $\delta_{\mathrm{H}} 1.32 \mathrm{ppm}$. Similarly, two other spin systems were assigned along $\mathrm{C}-\mathrm{H} 2\left(\delta_{\mathrm{H}} \mathrm{H}_{\mathrm{a}} 2.45 / \mathrm{H}_{\mathrm{b}} 2.53\right)$, oxygenated methine $\mathrm{C}-\mathrm{H} 3\left(\delta_{\mathrm{H}} 5.04\right)$ and aliphatic methylene $\mathrm{C}-\mathrm{H} 4\left(\delta_{\mathrm{H}}\right.$ 1.52) for subunit $\mathrm{C}$; and D-H2 $\left(\delta_{\mathrm{H}} \mathrm{H}_{\mathrm{a}} 2.29 / \mathrm{H}_{\mathrm{b}} 2.33\right)$, oxygenated methine D-H3 $\left(\delta_{\mathrm{H}}\right.$ 5.08) and aliphatic methylene D-H4 $\left(\delta_{\mathrm{H}} 1.46\right)$ for subunit $\mathrm{D}$, respectively. $\mathrm{HMBC}$ correlations from $\mathrm{B}-\mathrm{H} 3$ to $\mathrm{A}-\mathrm{C} 1$ and from $\mathrm{A}-\mathrm{H} 1$ to $\mathrm{B}-\mathrm{C} 3$ indicated that the $\alpha-$ rhamnopyranosyl group was connected to subunit B via a glycosidic bond. The ester bond between subunit $\mathrm{C}$ and $\mathrm{B}$ was deduced from HMBC correlations B-H2 and C-H3 to the carbonyl carbon at $\delta_{c} 170.3$. Similarly, the ester bond between subunit D and $\mathrm{C}$ was deduced from HMBC correlations C-H2 and D-H3 to carbonyl carbon at $\delta_{\mathrm{c}} 169.4$. The amide proton $\left(\delta_{\mathrm{H}} 7.54\right)$ from subunit $\mathrm{E}$ and $\alpha$-methylene protons $\mathrm{D}-\mathrm{H} 2\left(\delta_{\mathrm{H}}\right.$ $\mathrm{H}_{\mathrm{a}} 2.29 / \mathrm{H}_{\mathrm{b}} 2.33$ ) showed HMBC correlations to the carbonyl carbon at $\delta_{\mathrm{c}} 168.7$, providing the connectivity between subunits $\mathrm{D}$ and $\mathrm{E}$.

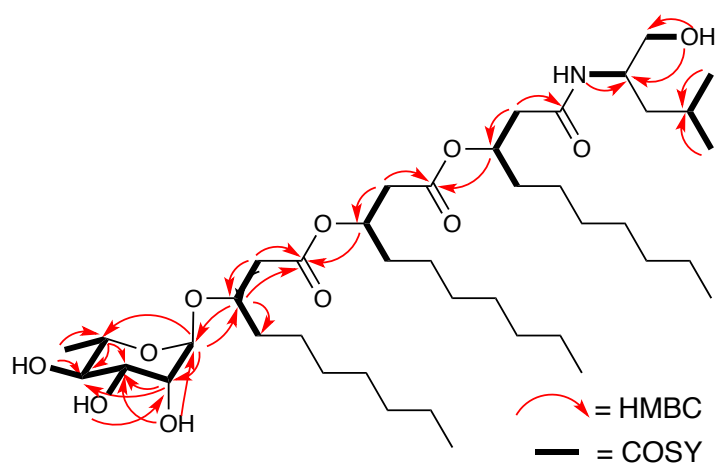

Figure 2. Key ${ }^{1} \mathrm{H}-{ }^{1} \mathrm{H}$ COSY and HMBC correlations of $\mathbf{1}$.

The length of each fatty acid chain for subunits B, C and D could not be resolved by NMR data alone. To address this issue, tandem mass spectrometry (MS/MS) was performed on the precursor ion $m / z 774.5674[\mathrm{M}+\mathrm{H}]^{+}$. As illustrated in Figure 3, fragment ions at $\mathrm{m} / \mathrm{z} 628.5108$ and $\mathrm{m} / \mathrm{z} 610.5000$ were detected as loss of the rhamnose residue $(-146 \mathrm{Da})$ and with additional loss of $\mathrm{H}_{2} \mathrm{O}(-164 \mathrm{Da})$, respectively, indicating fragmentation across the glycosidic bond. Minor fragment ions at $\mathrm{m} / \mathrm{z} 458.3804$ and $\mathrm{m} / \mathrm{z} 440.3707$ were detected as loss of one terminal fatty acyl chain $\left(\mathrm{C}_{10} \mathrm{H}_{18} \mathrm{O}_{2},-170 \mathrm{Da}\right)$ from product ions $m / z 628.5108$ and $\mathrm{m} / \mathrm{z} 610.5000$, respectively. Similarly, fragment ions m/z 288.2508 and $\mathrm{m} / \mathrm{z} 270.2414$ were detected as further loss of a terminal fatty acyl chain $\left(\mathrm{C}_{10} \mathrm{H}_{18} \mathrm{O}_{2},-170\right.$ Da). The N-(3-hydroxydecanoyl)-leucinol ( $\mathrm{m} / \mathrm{z} 288.2508)$ and its dehydrated ion were left with no further visible fragmentations. From these data, all subunits $\mathrm{B}, \mathrm{C}$ and $\mathrm{D}$ in $\mathbf{1}$ have $\mathrm{C}_{10}$ backbones.

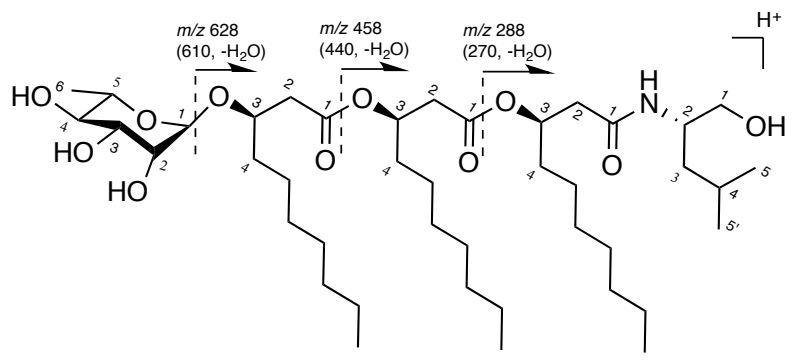

Figure 3. Fragments of 1 by ESI-MS/MS.

To determine the absolute configuration of the oxygenated methines, the 3-hydroxydecanoic acids were isolated following complete hydrolysis of $\mathbf{1}$. The optical rotation of the $1: 1: 1$ mixture was measured as $[\alpha]_{\mathrm{D}}^{25}-18.2\left(c 0.1 . \mathrm{CHCl}_{3}\right)$, which is in agreement with the reported optical rotation of $(R)-3$ hydroxydecanoic acid $\left([\alpha]^{25}-17.5\left(c 0.9 \mathrm{CHCl}_{3}\right) .{ }^{15}\right.$ Therefore, all three 3-hydroxyldecanoic acid subunits possess the $R$ configuration, in agreement with other bacterial rhamnolipids. ${ }^{1}$

1 showed cytotoxicity with $\mathrm{IC}_{50}$ of $6.9 \mu \mathrm{M}$ in BV-2 (murine microglia) and $\mathrm{IC}_{50}$ of $22 \mu \mathrm{M}$ in HAPI (rat microglia). 1 was also tested for antimicrobial activities against Staphylococcus aureus, Escherichia coli and Pseudomonas aeruginosa PAO1, but no visible growth inhibition was observed. 
In summary, we identified a novel rhamnolipid-amino alcohol hybrid rhizoleucinoside (1) from Bradyrhizobium sp. BTAi1. Its uniqueness lies in the incorporation of an amino alcohol moiety and the unprecedented rhamnolipid core structure that includes three sequential $\beta$-hydroxydecanoic acids. While the ecological role of this molecule requires further investigation, evidence suggests its possible role in establishstep to forming the symbiotic relationship between rhizobial bacteria and plant involves invasion of root cells. ${ }^{16}$ Legume immune systems can be triggered during the infection but become rapidly suppressed. ${ }^{17}$ Recent studies ${ }^{18,19}$ have suggested that Nod factors (NFs), a group of signal molecules widely produced by rhizobium, may be responsible for plant immuniyrhizobium sp. BTAil is reported to lack the genes nod $A B C$, which are essential for the production of NFs. ${ }^{11}$ Alhede $e t a l^{20}$ postulates that rhamnolipids produced by the pathogen $P$. aeruginosa function as a shield to thwart the immune responses during infections of a human host. Further investigation will be required to determine if rhizoleucinoside plays a role for Bradyrhizobium sp. BTAil in suppressing the host plant defense system and facilitating the establishment of symbiosis.

\section{ASSOCIATED CONTENT}

\section{Supporting Information}

Experimental details, the HRESIMS, MS/MS, NMR spectra and biological activity of $\mathbf{1}$. The Supporting Information is available free of charge on the ACS Publications website.

\section{AUTHOR INFORMATION}

\section{Corresponding Author}

*Email: hongw@zjut.edu.cn

*Email: drowley@uri.edu

\section{Author Contributions}

${ }^{\S}$ These authors contributed equally to this work. Notes

The authors declare no competing financial interest.

\section{ACKNOWLEDGMENT}

Instruments used for chemical analyses were supported by an Institutional Development Award (IDeA) from the National Institute of General Medical Sciences of the National Institutes of Health (grant number 2 P20 GM103430). NMR data was acquired at a research facility supported in part by the National Science Foundation EPSCoR Cooperative Agreement \#EPS-1004057. J.C. was supported in part by the China Scholarship Council (File no. 201408330156) ing the symbiosis between plant host and bacterium. The first ty suppression. Interestingly, as a unusual phenomenon, BradB.; Pignol, D.; Stacey, G.; Emerich, D.; Verméglio,

\section{REFERENCES}

Giraud, E.; Moulin, L.; Vallenet, D.; Barbe, V.; Cytryn, E.; Avarre, J.-C.; Jaubert, M.; Simon, D.; Cartieaux, F.; Prin, Y.; Bena, G.; Hannibal, L.; Fardoux, J.; Kojadinovic, M.; Vuillet, L.; Lajus, A.; Cruveiller, S.; Rouy, Z.; Mangenot, S.; Segurens, B.; Dossat, C.; Franck, W. L.; Chang, W.-S.; Saunders, E.; Bruce, D.; Richardson, P.; Normand, P.; Dreyfus, A.; Médigue, C.; Sadowsky, M. Science 2007, 316, 1307-1312.

Jarvis, F. G.; Johnson, M. J. J. Am. Chem. Soc. 1949, 71, 4124-4126. Microbiol. Biotechnol. 2010, 86, 1323-1336.

Microbiol. Biotechnol. 2005, 68, 718-725.

FEMS Microbiol. Lett. 2009, 295, 82.

Nayak, A. S.; Vijaykumar, M. H.; Karegoudar, T. B. Int Biodeterior. Biodegrad. 2009, 63, 73-79.

Heine, H.; Zähringer, U.; Brandenburg, K. Biol. Chem. 2006, 387, 301-310.

BMC Microbiol. 2009, 9, 1-12. 2233-2235

Zeng, Y.-B.; Wang, H.; Zuo, W.-J.; Zheng, B.; Yang, T.; Dai, H.-F.; Mei, W.-L. Mar. Drugs 2012, 10, 598603.

Fujii, K.; Ikai, Y; Mayumi, T; Oka, H; Suzuki, M; Harada, K. Anal. Chem. 1997, 69, 3346-3352. Cartwright, N. J. Biochem. J. 1957, 67, 663-669. Murray, J. D. Mol. Plant-Microbe Interact. 2011, 24, 631-639.

Gourion, B.; Berrabah, F.; Ratet, P.; Stacey, G. Trends Plant Sci. 2015, 20, 186-194.

Sugawara, M.; Sadowsky, M. J. Mol. Plant-Microbe Interact. 2014, 27, 328-335.

Liang, Y.; Cao, Y.; Tanaka, K.; Thibivilliers, S.; Wan, J.; Choi, J.; Kang, C. H.; Qiu, J.; Stacey, G. Science 2013, 341, 1384-1387.

Alhede, M.; Bjarnsholt, T.; Jensen, P. Ø.; Phipps, R. K.; Moser, C.; Christophersen, L.; Christensen, L. D.; van Gennip, M.; Parsek, M.; Høiby, N.; Rasmussen, T. B.; Givskov, M. Microbiology 2009, 155, 35003508.
Abdel-Mawgoud, A. M.; Lepine, F.; Déziel, E. Appl. 